\title{
当帰四逆加呉荣莫生姜湯の血管性間歇性跛行に 対する臨床効果
}

\author{
城島久美子 \\ 帝京大学医学部外科学講座, 東京, $=173-8605$ 板橋区加賀 2-11-1

\begin{abstract}
The Clinical Effectiveness of Traditional Japanese Harbal-medicine, Tokishigyakukagoshuyushyokyoto for Vascular Intermittent Claudication
\end{abstract}

\author{
Kumiko JYOJIMA \\ Department of Surgery, Teikyo University School of Medicine, 2-11-1 Kaga, Itabashi-ku, Tokyo 173-8605, Japan
}

\begin{abstract}
The clinical effects of tokishigyakukagoshuyushyokyoto for vascular intermittent claudication were investigated by treadmill test with $2.4 \mathrm{~km} /$ hour and 12 degree. Thirty three patients with Arteriosclerosis Obliterans (ASO) chose either administration of cilostazol (Group I ) or tokishigyakukagoshuyushyokyoto (Group II). After limitation of improvement by cilostazol in Group I, tokishigyakukagoshuyushyokyoto was administered (Group III). The distance where patients were able to walk to the limit was assumed to be the maximum walking distance. Change rate of absolute claudication distance (ACD) was calculated as ratio of maximum walking distance after and before treatment.

The median of change rate of ACD in Group I one and three month after treatment were $130.5 \%$ and 145.5 $\%$, respectively. The median of change rate of ACD in Group II one and three month after treatment were $111.6 \%$ and $122.7 \%$, respectively. Finally, the median of change rate of ACD in Group III one and three month after treatment were $112.0 \%$ and $112.3 \%$, respectively.

Either cilostazol or tokishigyakukagoshuyushyokyoto was effective for vascular intermittent claudication. Moreover, tokishigyakukagoshuyushyokyoto showed additional effect after limitation of improvement by cilostazol.

Key words : tokishigyakukagoshuyushyokyoto, vascular intermittent claudication, treadmill test, ASO, cilostazol

\section{要旨}

当帰四逆加吳茱薭生姜湯の血管性間歇性跛行に対する臨床効果を時速2. $4 \mathrm{~km}$ ，傾斜12\%のトレッドミル検查にて 検討した。血管性間歇性跛行を有する閉塞性動脈硬化症の患者33例を対象にし，投与薬は患者自身が選択した。I

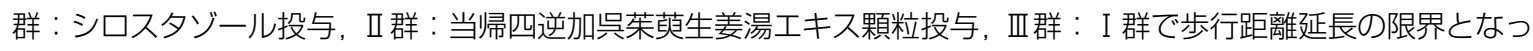
た患者に当帰四逆加吳茱喤生姜湯エキス顆粒投与した群とした。歩行限界まで歩いた距離を最大歩行距離とした。 その距離を最大歩行距離変化率（投与後距離／投与前距離×100）として算出した。

最大歩行距離変化率の中央值は，I 群で 1 力月後 $130.5 \%, 3$ 力月後 $145.5 \%$, I 群で 1 力月後 $111.6 \%, 3$ 力月後

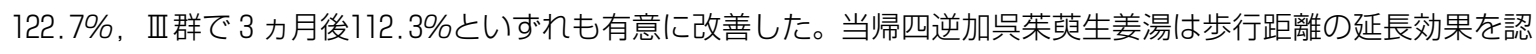
め, 単独治療およびシロスタゾールとの併用治療が有用であった。

キーワード : 当帰四逆加呉荣蕇生姜湯, 血管性間歇性跛行, トレッドミル検査, 閉塞性動脈硬化症, シロスタゾール
\end{abstract}

\section{緒言}

わが国の閉塞性動脈硬化症 (Arteriosclerosis Obliterans: ASO）の発生頻度を正確に調査した報告はな いが，潜在的な患者を含めると日本国民のうち約 400万人がASO に罹患していると推定されている1。
ASO を疑った場合は，上肢の血圧で高い方の血 圧を用いて, 下肢血圧/上腕血圧比 (Ankle Brachial Pressure Index: ABI）を測定する。ABI が0.9以下で ASO と診断される2)。ASOの症状の評価には, Fontain 分類が頻用されており ${ }^{3)}$, 約70\%が Fontain II 度 
の間歇性跛行を訴える患者である文。間歇性跛行と は一定距離を歩行するとそれ以上歩行ができなくな ることである。ASO などよる血管性間歇性跛行 の他に, 脊柱管狭窄症のような整形外科的疾患に よっても生じる。また間歇性跛行の評価をするには, トレッドミル検査で歩行距離を測定する事が最も信 頼性がある。しかし，施行場所の確保や時間的制約 などから臨床ではなかなか普及しておらず，多くの 場合は患者の主訴を頼りに処方しているのが現状で ある。ASO 患者の薬物治療は，わが国では臨床的 に, シロスタゾール, サルポグレラート塩酸塩など のいわゆる抗血小板剤が使用されている。わが国の 薬剂治験段階での評価は, いずれの薬剤も足趾潰瘍 の改善度に対して行われている。実際に血管性間歇 性跛行の歩行距離延長に有効な報告は, シロス夕 ゾール以外に我々が調べた限りなかった ${ }^{566)}$ 。

また漢方薬のひとつである当帰四逆加呉荣英生姜 湯は手足の冷えを伴う下腹部痛や腰痛症の患者に投

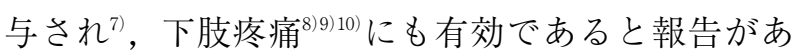
る。日常診療でも, 血管性間歇性跛行患者に当帰四 逆加只茱葫生姜湯が有効であった例をしばしば経験 する。しかし, 当帰四逆加吳荣䓎生姜湯の間歇性跛 行に対する有効性を示す研究報告はない。

そこで本研究では ASO 患者に当帰四逆加呉茱萌 生姜湯の血管性間歇性跛行に対する臨床効果を，卜 レッドミル検査にて調べた。また Trans-Atlantic InterSociety Consensus II (TASC II $)^{3)}$ において, ASO の 血管性間歇性跛行の第 1 選択薬とされているシロス タゾールとの臨床効果を比較検討した。さらにシロ スタゾールを投与されている患者に当帰四逆加呉荣 萌生姜湯を追加投与した場合の臨床効果も検討した。

\section{対象と方法}

2009年 4 月 1 日 2010年 4 月 31日の間に, 帝京大 学医学部附属病院血管外科外来を受診した患者の中 で，間歇性跛行を訴え，ABI が 0.9 以下を示す血管 性間歇性跛行を有する ASO 患者33例を対象とした。 年齢性別に特別な基準を設けなかった。あわせて脳 血管障害により歩行障害のある患者, 内分泌代謝異 常による下肢神経障害がある患者, 腰部脊柱管狭窄 症・腰椎椎間板へルニアなどの整形外科的疾患があ る患者, 心肺機能に重篤な障害がある患者を対象か ら除外した。すべての対象患者においてサルポグレ ラート塩酸塩, エイコサペント酸エチル, チクロピ

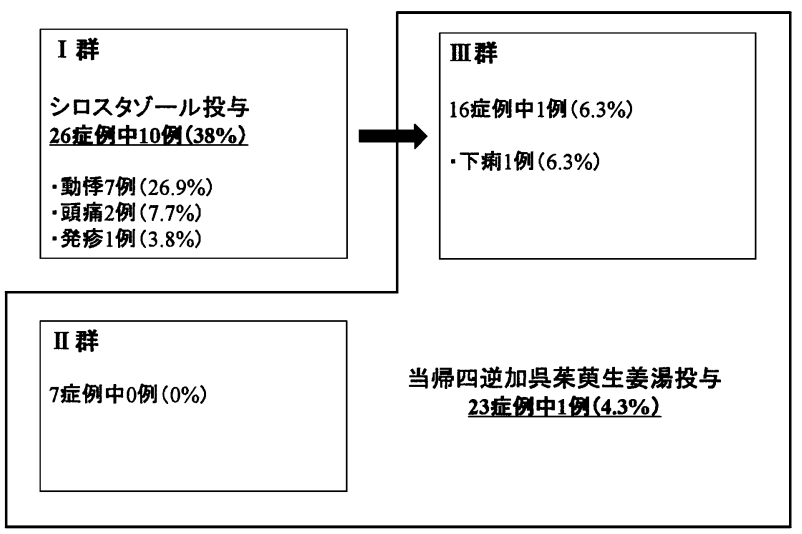

図 1 各投与群のフローチャート

ジン塩酸塩，アスピリン，ワルファリンカリウムな どの抗血小板剤や抗凝固剤のうち少なくとも一剂が 投与されていた。本研究で使用するシロスタゾール および当帰四逆加呉茱䓎生姜湯の投与歴がないもの を対象とした。

シロスタゾールはプレタール ${ }^{\circledR} 50 \mathrm{mg}$ および 100 mg（大塚製薬，東京）を使用した。投与方法は、 内服開始 1 週間は 1 回50 mg を 1 日 2 回内服とし、 それ以降は 1 回 $100 \mathrm{mg}$ を 1 日 2 回内服とした。こ の投与方法は副作用を軽減するために, 1 回の内服 を50 mg から開始し，期間をおいて100 mg に増量 することを製造元が推奨している方法である。当帰 四逆加呉茱药生姜湯は当帰四逆加呉茱䓎生姜湯エキ ス顆粒（ツムラ，東京， $7.5 \mathrm{~g} /$ 日）を使用し，投与 方法は 1 回 $2.5 \mathrm{~g}$ を 1 日 3 回食前に内服とした。

トレッドミル検査は電動トレッドミル DK-100 (DAIKOU, 東京) を使用し, 帝京大学医学部附属 病院血管外科外来に設置して行った。時速 $2.4 \mathrm{~km}$ で行い，傾斜 $12 \%$ として， 8 分 $(320 \mathrm{~m})$ を上限とし て歩行距離を測定した。最初に違和感を訴えた無症 候歩行距離（Initial claudication distance：ICD）と, トレッドミルの速さについて行けず歩行困難になる 最大歩行距離（Absolute claudication distance：ACD） を測定した。測定は15分以上の休憩をはさんで 2 回 以上行い, 平均值を算出した。片手のみ手すりの把

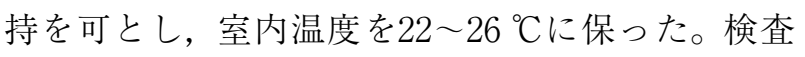
期間中に投与した薬剂以外の内服薬に変更がないこ とを確認した。

投与薬剂は対象患者の希望により選択させ, 対象 患者を I 群：シロスタゾール投与群，II群：当帰四 逆加呉茱萠生姜湯投与群に分類した。少なくとも投 
表 1 患者背景

\begin{tabular}{|c|c|c|c|c|c|}
\hline & $\begin{array}{l}\text { 全症例 } \\
n=23\end{array}$ & $\begin{array}{l}\text { I 群 } \\
\mathrm{n}=16\end{array}$ & $\begin{array}{l}\text { II 群 } \\
\mathrm{n}=7\end{array}$ & $\begin{array}{l}\text { III群 } \\
\mathrm{n}=15\end{array}$ & P值 \\
\hline $\begin{array}{l}\text { 年齢 } \pm \text { SD } \\
\text { (min } \sim \max \text { ） }\end{array}$ & $\begin{array}{c}71.3 \pm 8.01 \\
(56 \sim 83)\end{array}$ & $\begin{array}{c}71.1 \pm 8.14 \\
(57 \sim 83)\end{array}$ & $\begin{array}{c}71.9 \pm 8.3 \\
(56 \sim 79)\end{array}$ & $\begin{array}{c}72.0 \pm 7.57 \\
(57 \sim 83)\end{array}$ & NS** \\
\hline 性別(男:女) & $18: 5$ & $12: 4$ & $6: 1$ & $11: 4$ & NS* \\
\hline 喫煙 & $22(95.7 \%)$ & $15(93.8 \%)$ & $7(100 \%)$ & $15(100 \%)$ & NS* \\
\hline $\begin{array}{c}\text { Brinkman index } \\
\text { (一日本数 } \times \text { 年数 } \\
\quad \pm \mathrm{SD}\end{array}$ & $\begin{array}{c}1191.7 \\
\pm 573.1\end{array}$ & $\begin{array}{c}1160.9 \\
\pm 642.7\end{array}$ & $\begin{array}{c}1257.9 \\
\pm 422.0\end{array}$ & $\begin{array}{c}1160.9 \\
\pm 642.7\end{array}$ & NS** \\
\hline 糖尿病 & $12(52.2 \%)$ & $7(43.8 \%)$ & $5(71.4 \%)$ & $7(46.7 \%)$ & NS* \\
\hline 高血压症 & $19(82.6 \%)$ & $12(75.0 \%)$ & $7(100 \%)$ & $12(80.0 \%)$ & NS* \\
\hline 高脂血症 & $13(56.5 \%)$ & $9(56.3 \%)$ & $4(57.1 \%)$ & $8(53.3 \%)$ & NS* \\
\hline $\begin{array}{l}\text { 浩费前 } \\
\mathrm{ICD}(\mathrm{m}) \pm \mathrm{SD}\end{array}$ & $52.4 \pm 21.5$ & $53.3 \pm 23.9$ & $50.4 \pm 16.0$ & $63.2 \pm 27.9$ & NS** \\
\hline 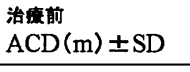 & $90.3 \pm 38.7$ & $92.1 \pm 43.0$ & $86.4 \pm 28.7$ & $101.0 \pm 34.8$ & NS** \\
\hline
\end{tabular}

表 2 内服薬と併用薬剂数

内服䔞

\begin{tabular}{|c|c|c|c|c|c|}
\hline & $\begin{array}{c}\text { 全症例 } \\
\mathrm{n}=23\end{array}$ & $\begin{array}{r}\text { I 群 } \\
\mathrm{n}=16\end{array}$ & $\begin{array}{r}\text { II 群 } \\
\mathrm{n}=7\end{array}$ & $\begin{array}{l}\text { IIII 群 } \\
\mathrm{n}=15\end{array}$ & P值* \\
\hline サルポグレラート眚㸗塩 & 19 & 12 & 7 & 11 & NS \\
\hline アスピリン & 7 & 5 & 2 & 4 & NS \\
\hline エイコサペント酸エチル & 5 & 4 & 1 & 4 & NS \\
\hline チクロピジン塩酸塩 & 1 & 1 & 0 & 1 & NS \\
\hline ワーファリン & 2 & 2 & 0 & 2 & NS \\
\hline シロスタソール & - & - & - & 15 & - \\
\hline
\end{tabular}

併用薬绪数

\begin{tabular}{|c|c|c|c|c|c|}
\hline & $\begin{array}{c}\text { 全症例 } \\
\mathrm{n}=23\end{array}$ & $\begin{array}{l}I \text { 群 } \\
\mathrm{n}=16\end{array}$ & $\begin{array}{l}\text { II 群 } \\
\mathrm{n}=7\end{array}$ & $\begin{array}{l}\text { III 群 } \\
\mathrm{n}=15\end{array}$ & P值* \\
\hline 1剂 & 13 & 9 & 4 & 0 & $<0.05$ \\
\hline 2敖 & 9 & 6 & 3 & 9 & NS \\
\hline 3敖 & 1 & 1 & 0 & 5 & $<0.05$ \\
\hline 4敖 & 0 & 0 & 0 & 1 & NS \\
\hline
\end{tabular}

I 解:シロスタソール投与

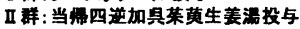

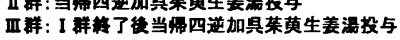

与前と投与 1 力月後と投与 3 力月後に, ICD と ACD をトレッドミルにて測定した。さらにI群に おいて 3 カ月後以降も毎月トレッドミル検査を行 い， 8 カ月後の時点で $\mathrm{ACD}$ の延長が限界になって いる患者を対象に当帰四逆加吳茱菶生姜湯をさらに 追加投与した。これを西群とした（図１）。

本研究は帝京大学医学部倫理委員会（帝医倫08 106号）の承認を得て行い，検査施行前にすべての 対象患者に規定の説明書を用いて説明し，書面で同 意を得た。

解析方法
各群の投与前の歩行距離 ICD（m）または ACD （m）を $100 \%$ とし，投与後の各歩行距離変化率（投 与後の歩行距離 $(\mathrm{m}) /$ 投与前の歩行距離 $(\mathrm{m}) \times$ 100\%）を算出した。解析は Stat Mate III（アトムス， 東京）を用いて，投与前後の各歩行距離変化率は Wilcoxonの符号付順位検定で行った。またI群お よび I 群の群間比較は Mann-Whitney U 検定で行っ た。ともに $\mathrm{P}<0.05$ をって有意差ありと判断した。

\section{結果}

ASO 患者33例のうち副作用が認められた脱落例 10例を除外し, 検討対象は23例（男性18例，女性 5 


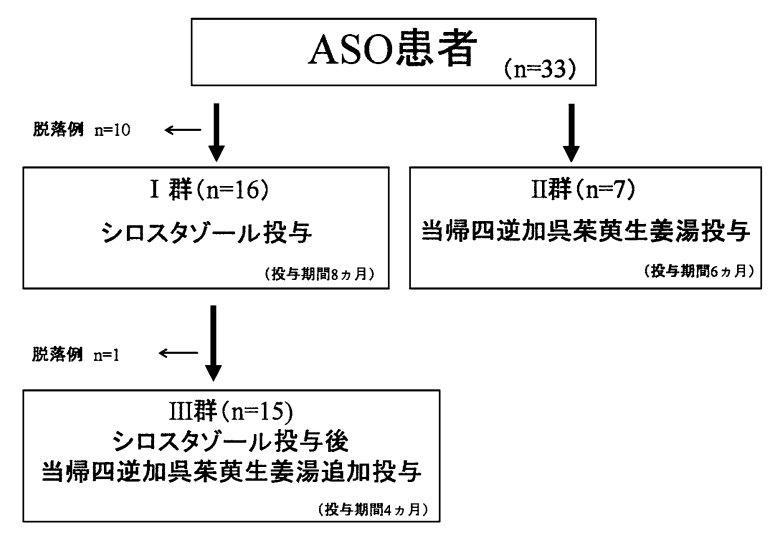

図2 各投与群での薬剂副作用とその出現率

例）であった。年齢は56～83歳，契煙歴は22例 (95.7\%）にあった。非契煙者の 1 例は糖尿病と高 脂血症を合併していた。また高血圧症合併患者は19 例（82.6\%）であった（表 1$)$ 。

抗血小板剂および抗凝固剂服用歴は、I 群, II 群 ともにサルポグレラート塩酸塩, 次にアスピリンの 服用が多かった。単剂ではなく 2 剂以上併用してい る患者が10例で全体の43.5\%であった（表 $2 ） 。$

ASO 患者33例のうちシロスタゾールを投与した 患者は26例で，10例（38\%）で副作用が出現した。 動悸 7 例 $(26.9 \%)$, 頭痛 2 例 $(7.7 \%)$, 発疹 1 例 (3.8\%) であった。また当帰四逆加呉茱草生姜湯 を投与した患者は，ASO患者33例のうちI群終了 の16例と II 群 7 例で，全23例中 1 例 $(4.3 \%)$ で下 痢が出現した（図２）。I群では16例が，【群では 7 例が，III群では15例がトレッドミル検査を完遂で きた（図 1 )。

I 群の ICD 変化率の中央值（25パーセンタイル， 75パーセンタイル）は，1 月月後 $135.0 \%$ (116.9, 187.1)，3力月後 $165.3 \%(133.6 ， 187.7 ）$ となり， 投与前と 1 力月後, 投与前と 3 力月後で有意に改善 した。またI群では 1 カ月後110.3\% (105.0, 122.4)， 3 力月後 $113.0 \%(111.2,139.5)$ となり, 投与前 と 1 力月後，投与前と 3 力月後で有意に改善した。

I 群および!群の ICD変化率の群間比較では 1 カ 月後， 3 力月後ともに有意差を認めなかった。 III群 の ICD 変化率は 1 力月後 $105.2 \%(84.4,123.3), 3$ 力月後 $121.3 \%(101.1 ， 148.0)$ となり，投与前と 3 カ月後で有意に改善した（図 3 )。

I 群の ACD 変化率の中央值は， 1 力月後 $130.5 \%$ (109.4，154.8）と 3 力月後145.6\% (111.6，171.8) となり, 投与前と 1 力月後, 投与前と 3 力月後で有
意に改善した。【I群では 1 カ月後111.6\%（104.8， 124.1)，3 カ月後 $122.7 \%(111.5 ， 127.3)$ となり， 投与前と 1 力月後, 投与前と 3 力月後で有意に改善 した。I群およびI群の ACD 変化率の群間比較で は 1 力月後， 3 力月後ともに有意差はなかった。 III 群の ACD 変化率は 1 力月後 $112.0 \%(90.5,116.9)$, 3 力月後 $112.3 \%(101.3,131.6)$ となり, 投与前 と 3 カ月後で有意に改善した（図 4 )。

\section{考察}

わが国でASO と呼ばれる疾患は，世界的には末 梢動脈閉塞性疾患（Peripheral arterial disease：PAD） と呼ばれている。欧米の PADの発生頻度の報告で は，38～82歳で2.2\%とするものから55～70歳で $17 \%$ とするものまで幅がある ${ }^{11}$ 。わが国も含め世界 的に人口構成の高齢化に伴って増加傾向を示してい る $^{1112)}$ 。

ASO の症状の評価には, Fontain 分類が頻用され ている3゙。Fontain I 度は冷感または無症状，II度は 間歇性跛行， III度は安静時痛，IV 度は切迫壊死であ る。間歇性跛行には，ASO などの血管疾患による 血管性間歇性跛行は $11.1 \%$ ，整形外科的疾患による 間歇性跛行は $72.7 \%$ ，そして $14.5 \%$ は両者が併存し ていると報告されている ${ }^{13)}$ 。整形外科的疾患による 間歇性跛行は腰椎の屈曲などにより軽減するのに対 して，血管性間歇性跛行の特徴は立位の休憩のみで 再び歩行が可能になることである。しかし血管性と 整形外科的間歇性跛行が合併している例もあるため, 必ず足部の動脈拍動を調べる必要がある。

ASO 患者の薬物治療は, TASC II ${ }^{3)}$ において, 第 一選択薬はシロスタゾールとされている。さらに米 国心臓病学会／米国心臓協会ガイドライン ${ }^{14)}$ でも, シロスタゾールがPAD および間歇性跛行の症状改 善と歩行距離改善に対して有効であるとされている。 しかし心不全合併例は禁忌であり，その副作用も懸 念されている。

本研究では投与薬を除いて, 全症例において研究 観察期間中に内服薬の変更はなかった。また ASO 患者では禁煙 ${ }^{15)}$ およひ運動療法 ${ }^{16)}$ で間歇性跛行の距 離が改善することが報告されている。そのため禁煙 を強く勧めたが，当院では禁煙外来がなかったため 1 例も禁煙を達成できなかった。また運動療法も当 院では積極的に施行していないため，この研究観察 期間中に血管性間歇性跛行の歩行距離が延長する可 


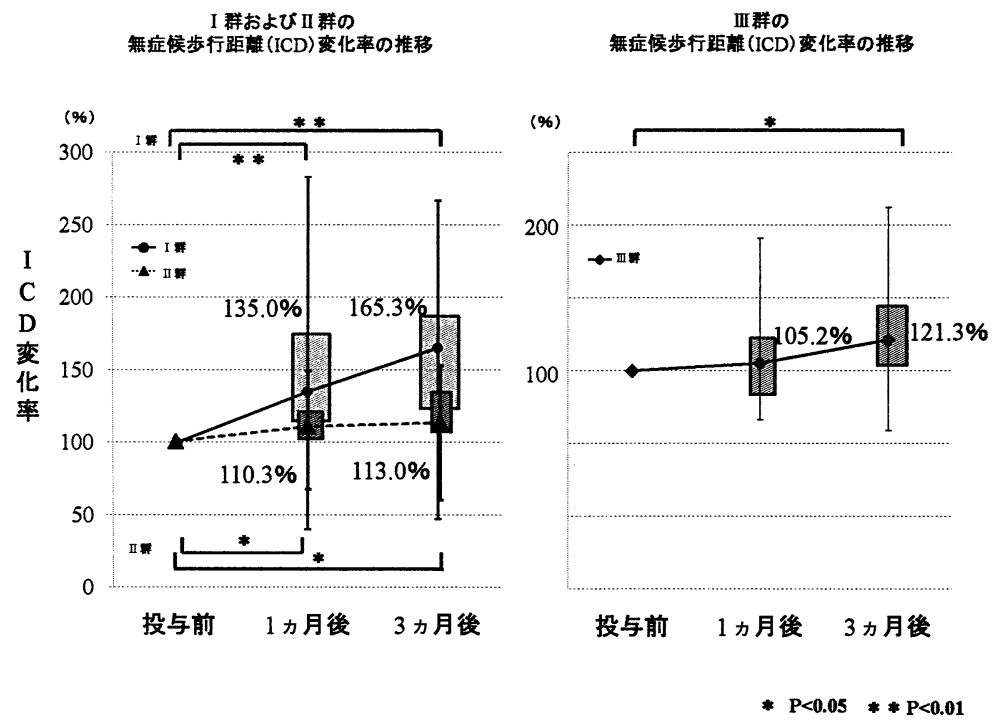

図 3 シロスタゾール，当帰四逆加呉茱薭生姜湯，当帰四逆加呉茱 萌生姜湯追加投与による無症候歩行距離（ICD）変化率の推移 ICD 変化率を箱ひげ図で示す。ひげの上端は最大值，下端は最小 值を示す。箱の上端は75パーセンタイル，箱の下端は25パーセンタ イルを示し，箱内のドットは中央值を示す。I 群II群において群間 比較したが有意差はなかった。
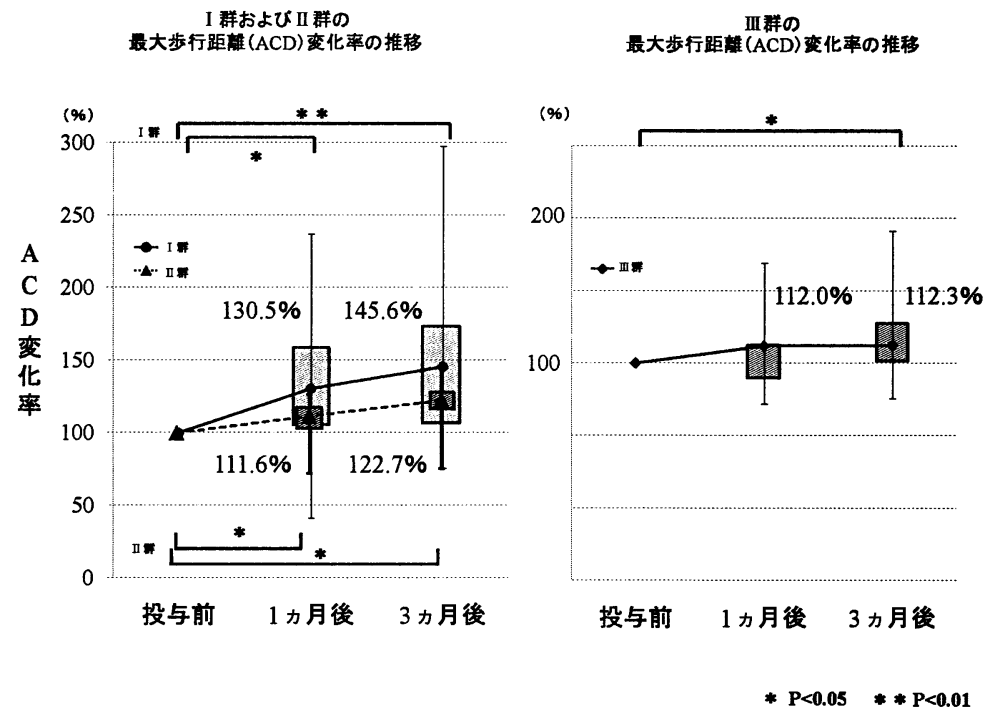

図 4 シロスタゾール，当帰四逆加呉荣莫生姜湯，当帰四逆加呉荣 英生姜湯追加投与による最大歩行距離 (ACD) 変化率の推移 $\mathrm{ACD}$ 変化率を箱ひげ図で示す。ひげの上端は最大值，下端は最小 值を示す。箱の上端は75パーセンタイル，箱の下端は25パーセンタ イルを示し，箱内のドットは中央值を示す。I 群II群において群間 比較したが有意差はなかった。

能性はほとんどないと考えられる。

間歇性跛行の評価はトレッドミル検査で行うのが 一般的だが，多くの場合はトレッドミル検査を行わ ず，薬剤の効果を患者への問診で判定している。問 診では実際の効果をどれだけ反映しているか推測す
ることは困難である。その理由として，今回の研究 中にも患者は投与された薬剤の効果があると述べて いながら，実際はトレッドミル検査で歩行距離が短 縮している例や，また反対にあまり効果がないとの 訴えでありながら歩行距離が延長している例を認め 
たことが挙げられる。一方で, トレッドミル検査の 問題点としては, 速度と傾斜が固定されていること である。患者が実は日常生活で全く問題ないと言っ ていても，実際にトレッドミル検査を施行すると， ICD や ACD が問診での歩行距離と比べ，短くなる 患者も散見された。実際に時速 $2.4 \mathrm{~km}$ で歩行する ことはASO 患者の日常生活と比べ速い速度である と思われる。患者の QOL とトレッドミル検査の歩 行距離が実際と比例していないことを示唆している。 患者自身は日常生活を送るうえで，ゆっくり歩行し たり，立ち止まって休䕀したり，歩行途中で速度を 落すなどして下肢虚血による症状が出現しないよう に無意識に自己調節しているのではないだろうか。 トレッドミル検査では速度および傾斜が一定で自己 調節できないために, 実際の歩行距離と比例してい ないのではないかと考えられる。しかし今回は敢え て患者個人による歩行速度の変更を認めずに, 全対 象患者一律で時速 $2.4 \mathrm{~km}$, 傾斜 $12 \%$ でトレッドミ ル検査を行い, 薬椷の臨床効果を調査した。

TASC II ${ }^{3)}$ の報告と同様に, 本研究でもシロス夕 ゾールの有効性は示された。しかし, シロスタゾー ルは38\%の患者に投与を中止するほどの副作用が出 現している (図 2 )。特に循環器系の副作用が頻発 するため, 十分な副作用を説明した上で使用する必 要がある。製品添付文書からも, 禁忌としてうっ血 性心不全, 慎重投与として糖尿病, 警告として狭心 症発作の副作用があげられている。また, 実はシロ スタゾールが，なぜ血管性間歇性跛行の歩行距離が 改善するかは明らかになっていない。もしも側副路 が増加し, 抗血小板剤の血管拡張作用にて血流が増 すのであれば，ABI は投与後に増加すると考えられ る。しかし，多くの文献は間歇性跛行の改善後にも ABI は無変化であるか, 増加してもわずか 0.1 程度

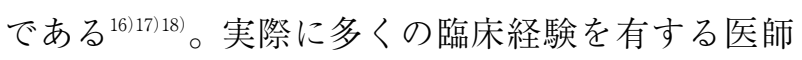
は，なぜ抗血小板剂が血管性間歇性跛行に有効かを 知りたいと考えているのが実情ではないかと思われ る。

一方で当帰四逆加呉荣䓎生姜湯が, シロスタゾー ルとともにトレッドミル検査で有意差を持って $\mathrm{ACD}$ 延長効果を認めたことは発見であった。さら にシロスタゾールの投与で ACD 延長が見られなく なった状態でも当帰四逆加呉茱萌生姜湯投与により さらに $\mathrm{ACD}$ 延長を認めたことも新たな発見であっ
た。副作用も下痢 1 例のみであった。下痢は当帰四 逆加只荣英生姜湯に含まれる当帰によるものと考え られ，患者に副作用の可能性は説明済みであった。

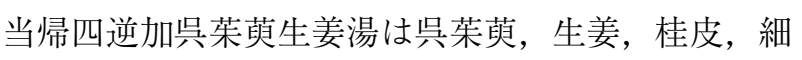
辛, 当帰, 药薬, 甘草, 大霖, 木通により 9 種類の 生薬で構成されている。抗血小板作用は当帰, 桂皮, 生姜, 甘草にあると言われている。末梢血管拡張作 用は桂皮, 点茱䓎, 大雵, 药薬にあり, 鎮痛・鎮痓 作用は药薬, 木通が有していると言われている ${ }^{192021)}$ 。 また同薬を用いた皮膚温の改善効果 ${ }^{22}$ や, ASO によ る下肢慢性疼痛の改善 ${ }^{10)}$ 報告されている。有効成 分としては, 桂皮の cinnamaldehyde ${ }^{2324)}$ や莐薬 paeoniflorin ${ }^{25}$ などがある。漢方は複数生薬の調合とし て発展し, 一方で副作用を減らし, 新しい効果を作 り上げてきたものである。今回の血管性間歇性跛行 の歩行距離に改善効果を示した原因もその相乗, 相 加作用と推測される。

臨床医が重視するのは，患者の主訴の改善である。 血管性間歇性跛行の歩行距離の改善に対して抗血小 板剤および漢方薬も西洋医学的に機序は解明されて いない。しかし患者の主訴の改善という目的に対し て, 本研究の結果から抗血小板剤および漢方薬を単 剤ではなく併用で使用することも意味があると思わ れる。また抗血小板剤同志の併用よりも, 抗血小板 剂と漢方薬を併用することで薬剤費は数分の 1 程度 に抑えることができ, 経済的負担の軽減も可能であ ると考えられる。今までの報告では, 血管性間歇性 跛行と思われる症状に当帰四逆加呉茱莫生姜湯が有 効であるという報告は調べる限りでは認めなかった。 そのため, 歩行距離延長効果は当初は考えていな かった。現代の西洋医学的視点で漢方薬の効果を一 方的に否定することなく, 当帰四逆加尅茱萌生姜湯 を血管性間歇性跛行の治療薬として選択することは 新しい1つの方法であると認識した。

本研究はランダム化試験ではなく, またコント ロール群があれば望ましいと思われた。トレッドミ ル検査施行者は投与薬を知らないため, その点にお いては片側のブラインドは保たれていたと思われた。 今後の研究のさらなる改善課題としてあげられた。

\section{結語}

当帰四逆加乶茉葫生姜湯は血管性間歇性跛行に対 し, 歩行距離の延長効果を認め, 単独治療だけでな くシロスタゾールとの併用治療が有用であった。 
謝辞＼cjkstart稿を終えるにあたり，帝京大学医学部外科宮 澤幸久教授に感謝の意を表します。そしてご指導ご校 閲いただきました帝京大学医学部外科新見正則准教授 に深甚なる感謝の意を表します。さらに帝京大学病院 外科白土裕之先生, 財団法人愛世会愛誠病院小池洋介 先生に厚く御礼申し上げます。

なお本論文の内容の一部は，第50回日本脈管学会に て発表した。

\section{引用文献}

1) 重松 宏, 新しい診断と治療の $\mathrm{ABC} 60 /$ 循環器10 閉 塞性動脈硬化症 最新医学別冊, 最新医学社, 東京, 2009

2 ) Orchard TJ, Strandness DE Jr: AHA Medical/Scientific Statement, Workshop Proceedings, Assessment of Peripheral Vascular Disease in Diabetes, Report and Recommendations of an International Workshop Sponsored by the American Diabetes Association and the American Heart Association September 18-20, 1992 New Orleans, Louisiana, Circuration, 88, 819-828, 1993

3 ) Norgren L, Hiatt WR, Dormandy JA, Nehler MR, Harris KA, Fowkes FG, Rutherford RB; TASC II Working Group. : Inter society consensus for the management of peripheral arterial disease (TASC II). J Vasc Surg 2007 ; 45 (Suppl)

4 ）重松 宏, 安田慶彦, 田辺達三: 重症虚血肢をめぐる 諸問題 日本の現状と診断基準, Therapeutic Reserch. 13(10). 4099-4109, ライフサイエンス出版, 東京都， 1992

5 ) Regensteiner JG, Ware JE Jr, McCarthy WJ, Zhang P, Forbes WP, Heckman J, Hiatt WR : Effect of Cilostazol on Treadmill Walking, Community-based Walking Ability, and Health-Related Quality of Life in Patients with Intermittent Claudication Due to Peripheral Arterial Disease : Meta-Analysis of Six Randomized Controlled Trials. Journal of American Geriatrics Society, 50 (12), 1939-1946, 2002

6) Cosmi B, Conti E, Coccheri S : Anticoagulants (heparin, low molecular weight heparin and oral anticoagulants) for intermittent claudication. Cochrane Database Syst Rev 2001(3) : CD001999

7 ）大塚敬節：傷寒論解説, 460-463, 創元社, 大阪, 1966

8 ）黑川扸臣, 玉熊正悦：各種疼痛に対する漢方併用の治 療経験，痛みと漢方， 6, 72-78, 1996

9 ）山上裕章, 住田剛, 橋爪圭司, 奥田孝雄 : 腰部脊椎管 狭窄症に対する当帰四逆加点茱䓎生姜湯の効果, 日本 東洋医学雑誌，42(3)，331-335，1992

10）及川 欧，藤木直人，松本昭久，田代邦雄，五十嵐美 加, 筒井末春 : 閉塞性動脈硬化症（ASO）による下肢 慢性疼痛に対する複合的治療の試み一自律訓練法, 筋 電図バイオフィードバック法と漢方一, 日本東洋心身 医学研究, $14: 68-75,1999$
11) Taylor LM Jr, Moneta GL, Porter JM : Natural history and Nonoperative treatment of chronic lower extremity ischemia. in Vascular Surgery ( 5 thed) (Rutherford RB edition), 928-943, 2000

12）三島好雄：特集によせて（特集 閉塞性動脈硬化症）, 日本外科学会誌，97，467-470，1996

13）鳥畠康充，沢村英一郎，鹿野尚英，北川清秀，斎藤 裕：整形外科を受診した間歇性跛行患者における慢性 動脈閉塞症の割合および診断法, 整形 - 災害外科学会 誌，45，665-674，2002

14) American College of Cardiology: ACC/American Heart Association : AHA 2005 Practice Guidelines for the management of patients with peripheral arterial disease (lower extremity, renal, mesenteric, and abdominal aortic) : a collaborative report from the American Association for Vascular Surgery/Society for Vascular Surgery, Society for Cardiovascular Angiography and Interventions, Society for Vascular Medicine and Biology, Society of Interventional Radiology, and the ACC/AHA Task Force on Practice Guidelines (Writing Committee to Develop Guidelines for the Management of Patients With Peripheral Arterial Disease) : endorsed by the American Association of Cardiovascular and Pulmonary Rehabilitation; National Heart, Lung, and Blood Institute ; Society for Vascular Nursing ; TransAtlantic Inter-Society Consensus ; and Vascular Disease Foundation. Hirsch AT, Haskal ZJ, Hertzer NR, Bakal CW, Creager MA, Halperin JL, Hiratzka LF, Murphy WR, Olin JW, Puschett JB, Rosenfield KA, Sacks D, Stanley JC, Taylor LM Jr, White CJ, White J, White RA, Antman EM, Smith SC Jr, Adams CD, Anderson JL, Faxon DP, Fuster V, Gibbons RJ, Hunt SA, Jacobs AK, Nishimura R, Ornato JP, Page RL, Riegel B, Circuration, 113(11), 1, e463-654, 2006

15) Keo H, Grob E, Guggisberg F, Widmer J, Baumgartner I, Schmid JP, Kalka C, Saner H. : Long-term effects of supervised exercise training on walking capacity and quality of life in patients with intermittent claudication.VASV, 37 (3) , 250-256, 2008

16）林富貴雄, 竹下 聡, 圷 宏一, 野々木宏: 間歇性跛 行肢に対する運動療法の有用性, 脈管学, 46, 539542, 2006

17) Mark E, O'Donnell, DSEM, MD, MFSEM MRCS, The Vascular and Biochemical Effects of Cilostazol in Diabetic Patients With Peripheral Arterial Disease, Vascular and EndoVascular, Vol.43, No 2, 2009

18）鳥畠康充, 谷内直人, 西田政史：Arterial Stiffness 動 脈壁の老化と硬化，4，41-45，2003

19) Kanai S, Okano H, Abe H: Efficacy of Tokishigyakukagoshuyu-syoukyo-to (Danggui-Sini-Jia-Wuzhuyu-ShengjiangTang) on peripheral circulation in autonomic disorders. Am J Chin Med， $25 ：$ 69-78， 1997

20）鳥居塚和生, 当帰四逆加只荣萌生姜湯 漢方医学 vol27，236243，2003

21）武田大輔, 金井成行, 谷口典正, 楳田高士：実験的冷 
え症モデルラットに対する漢方薬の検討, 漢方と最新 治療 9，259-262，2000

22）金内日出男：レイノー病と慢性動脈閉塞症, 膠原病に おけるレイノー現象の臨床症状とサーモグラフィーを 用いた皮膚温との比較一当帰四逆加吳荣葫生姜湯の薬 効評価一 公立豊岡病院紀要, 11, 69-76, 1999

23) Harada M, Yano S: Pharmacological Studies on Chinese Cinnamon II. Effects of Cinnamaldehyde on the Cardiovascular and Digestive Systems. Chemical and Phamaceuti- cal Bulletin. 23(5), 941-947, 1975

24) Harada M, Saito A : Pharmacological Studies On Chinese Cinnamon IV. Effects of Cinnamaldehyde on the Isolated Heart of Guinea Pigs its Catecholamine releasing effect from the Adrenal Grand of Dogs : Journal of PharmacobioDynamics, 1, 89-97, 1978

25）高木敬次郎, 原田正敏: 药薬の薬理学的研究（第 3 報) ペオニフロリンの循環呼吸器系および摘出臓器に およぼす作用，薬理学雑誌，89(7)，893-898，1969 